\title{
KAJIAN DAKWAH PRANIKAH SAMARA YOUTH ISLAMIC STUDY CLUB AL-AZHAR PERSPEKTIF PSIKOLOGI REMAJA
}

\author{
Sri Wahyuni \\ STID Al-Hadid, Surabaya \\ sriwahyunisri@stidalhadid.ac.id
}

\begin{abstract}
Abstrak: Pernikahan merupakan kebutuhan manusia, namun dinamikanya tidak mudah. Kegagalan menjalani dinamika itu salah satunya bisa disebabkan kurangnya persiapan pranikah sejak mereka remaja. Salah satu kajian yang memberikan dakwah pranikah pada remaja adalah Samara Youth Islamic Study Club (YISC) Al-Azhar. Studi ini, hendak mengkaji hal tersebut dengan tujuan mengetahui kajian dakwah pranikah Samara YISC Al-Azhar perspektif psikologi remaja. Jenis studi ini adalah kualitatif deskriptif dengan metode penggalian data dokumentasi. Sumber datanya dari website resmi YISC Al-Azhar dan YouTube. Hasil dari studi ini, yakni kajian Samara sebagai usaha dakwah pranikah islami untuk remaja yang berkualitas baik. Hal tersebut, karena semua unsur dakwahnya meliputi tujuan, materi, dai, metode, dan media dakwah sudah menyesuaikan aspek psikologis remaja. Remaja yang termasuk mad'uw adalah remaja muslim umum, terutama di Jabodetabek. Kajian ini menyesuaikan aspek psikologis remaja yang terkait persiapan menikah, yakni: (1) persepsi tentang pernikahan (tujuan, usia menikah, kriteria calon pasangan, dan proses membina hubungan); (2) kebutuhan dalam membina hubungan; dan (3) problem saat membina hubungan (patah hati, seks pranikah, depresi, dan lainnya). Kajian ini bisa sebagai salah satu upaya agar remaja terhindar dari perilaku kedosaan saat remaja dan mengalami kegagalan pernikahan di kemudian hari.

Kata kunci: Kajian dakwah, pranikah, Samara YISC Al-Azhar, psikologi remaja.
\end{abstract}

YOUTH ISLAMIC STUDY CLUB AL-AZHAR'S PREMARITAL DA'WAH STUDY OF SAMARA THE PERSPECTIVE OF ADOLESCENT PSYCHOLOGY. Abstract: A marriage is a human need, but its dynamics are not easy. One of the failures in handling its dynamics is caused by a lack of premarital preparation since they are adolescents. One of the studies providing premarital da'wah to adolescents is Samara Youth Islamic Study Club (YISC) Al-Azhar. This study aims to examine the premarital study of Samara YISC Al-Azhar from the perspective of adolescent psychology. This descriptive literature study uses documentary data resources taken from the official website of YISC Al-Azhar and YouTube. It results that Samara study as a premarital study for adolescents is a well-qualified one. It is because all da'wah elements, including purposes, materials, preachers, methods, and da'wah media have adjusted aspects of adolescent psychology. Adolescents involved as mad'uw are general Moslem adolescents, especially in Jabodetabek. It adjusts aspects of adolescent psychology related to the marriage preparation, namely: (1) perceptions about marriage (purposes, age of marriage, criteria of couple candidates, and process of building relationship); (2) a need for building relationship; (3) problems when maintaining relationship (heart break, premarital sex, depression, and others). This study is one of the efforts to avoid adolescents in sinful behaviour and experience failure in their marriages in the future.

Key words: Da'wah Study, Premarital, Samara YSIC Al-Azhar, Adolescent Psychology 


\section{Pendahuluan}

Pernikahan adalah fitrah dari semua manusia. Dengan pernikahan, mampu meregenerasi kelompok sosial. Regenerasi kelompok sosial ini penting untuk keberlangsungan komunitas manusia serta melestarikan nilai-nilai, budaya, agama, atau lainnya ke generasi berikutnya. Di sisi lain, manusia sebagai makhluk individu dan sosial. Dia tidak akan bisa sendiri saja, pasti membutuhkan orang lain. Salah satunya, manusia yang normal akan memiliki ketertarikan dengan lawan jenisnya dan ingin melakukan hubungan untuk memenuhi kebutuhannya.

Allah memerintahkan agar manusia melakukan pernikahan untuk meneruskan keturunannya. Pernikahan tidak bisa dipisahkan dengan penghambaan manusia kepada Allah karena pernikahan tujuannya supaya manusia bertakwa. Hal ini, bisa dipahami dari Q.S. An-Nisa' ayat 1 yang artinya: "Wahai manusia! Bertakwalah kepada Tuhanmu yang telah menciptakan kamu dari diri yang satu (Adam), dan (Allah) menciptakan pasangannya (Hawa) dari (diri)-nya; dan dari keduanya Allah memperkembangbiakkan laki-laki dan perempuan yang banyak. Bertakwalah kepada Allah yang dengan nama-Nya kamu saling meminta, dan (peliharalah) hubungan kekeluargaan. Sesungguhnya Allah selalu menjaga dan mengawasimu." ${ }^{11}$

Kehidupan pernikahan tidak selalu bisa dijalani dengan mulus. Ketika dua orang individu disatukan dengan ikatan sah dan

1 Redaksi, “Qur'an Kemenag," accessed March 22, 2021, https://quran.kemenag.go.id/sura/4.

2 Rama Dhini Permasari Johar and Hamda Sulfinadia, "Manajemen Konflik Sebagai Upaya Mempertahankan Keutuhan Rumah Tangga," Journal Al-Ahkam XXI, no. 1 (2020): menjalani kehidupan jangka panjang, ternyata banyak sekali masalah yang bisa ditimbulkan. Konflik yang terjadi di dalam setiap rumah tangga bisa berupa konflik kecil sampai konflik yang besar. Bentuk konflik dalam rumah tangga adalah kekerasan secara verbal, berupa kata-kata kasar, menghina, ataupun cekcok secara verbal dengan pasangannya. Bentuk konflik lainnya adalah konflik dengan sikap bertahan, menarik diri dari pasangan, dan kekerasan secara fisik. ${ }^{2}$ Kasus perceraian di Indonesia setiap tahun semakin tinggi. Angka perceraian mengalami peningkatan setiap tahun sejak tahun 2015 (394.246 kasus), 2016 (401.717 kasus), 2017 (415.510 kasus), dan 2018 (444.358 kasus). Tahun 2020, per Agustus jumlahnya sudah mencapai 306.688 kasus. $^{3}$

Sebab dari adanya masalah rumah tangga hingga berujung pada perceraian bisa berbagai hal. Salah satunya adalah ketidaksiapan pasangan itu untuk menempuh bahtera rumah tangga. Kehidupan keluarga tidak hanya butuh cinta, tapi juga butuh kesiapan mental, ekonomi, komitmen untuk bertanggung jawab, dan lainnya. Berbagai hasil studi seperti yang dilakukan Tsania, Sunarti, dan Krisnatuti menunjukkan bahwa kurangnya kesiapan menikah berdampak pada masalah ekonomi, ketidakharmonisan keluarga, salah satu pasangan meninggalkan kewajiban, awal perkawinan yang kurang baik, kurangnya komunikasi dan penyelesaian

https://ejournal.uinib.ac.id/jurnal/index.php/alahkam /article/view/1476/pdf

${ }^{3}$ Insan Khoirul Qolbi, "Kemenag - BP4 Perkuat Sinergi, Tekan Angka Perceraian," accessed July 24, 2021 https://kemenag.go.id/read/kemenag-bp4-perkuatsinergi-tekan-angka-perceraian-xkv8g. 
masalah dengan baik. ${ }^{4}$ Ibarat orang mau perjalanan ke kota lain pasti membutuhkan persiapan agar bisa sampai ke tujuan dengan selamat dan tepat tujuan. Menikah juga membutuhkan persiapan yang tidak boleh sembarangan. Menurut Tsania, Sunarti, dan Krisnatuti, perceraian yang tinggi tersebut justru cenderung dilakukan oleh pasangan muda. Pasangan muda tersebut sesungguhnya belum memperhatikan kesiapan menikah. ${ }^{5}$

Persiapan sebelum menikah perlu dilakukan yakni terkait menambah pemahaman dan kesadaran akan seluk beluk pernikahan, cara menyiapkan pernikahan, dan cara mengatasi persoalan saat menikah. Pemahaman ini harus berdasarkan pada nilai-nilai Islam yang universal agar nantinya keluarga yang dibangun juga sesuai dengan perintah Allah Swt. Salah satu contoh kajian dakwah yang konsisten menyampaikan nilai-nilai Islam terkait persiapan menikah pada remaja adalah Kajian Samara yang diselenggarakan oleh YISC Al-Azhar. YISC Al-Azhar adalah organisasi kepemudaan Islam di bawah koordinasi Yayasan Pesantren Islam AlAzhar. ${ }^{6}$

YISC Al-Azhar adalah organisasi pemuda masjid yang pertama berdiri di tanah air yakni tanggal 16 Mei 1971 di Jakarta. Dalam dimensi kesejarahannya, organisasi ini

\footnotetext{
4 Nurlita Tsania, Euis Sunarti, and D.K. Pranaji, "Karakteristik Keluarga, Kesiapan Menikah Istri, Dan Perkembangan Anak Usia 3-5 Tahun," Jurnal IImu Keluarga Dan Konsumen 8, no. 1 (2015): 29, doi:10.24156/jikk.2015.8.1.28.

${ }^{5}$ Ibid.

${ }^{6}$ Redaksi, "Masjid Al-Azhar," accessed December 4, 2020, www.al-azhar.or.id/index.php/komunitas/.

7 Redaksi, "Latar Belakang," accessed April 15, 2021, http://www.yisc-alazhar.or.id/profil/.

${ }^{8}$ Redaksi, "YISC Al-Azhar," accessed December 4, 2020, www.yisc-alazhar.or.id/profil/.
}

muncul sebagai jawaban atas berbagai persoalan yang menghinggapi generasi muda pada masa itu yang sedang mengalami perubahan seiring dengan pola kebijaksanaan di tingkat lokal, nasional, dan global. ${ }^{7}$ Kajian di YISC Al-Azhar secara umum memiliki peminat yang tinggi, mencapai 1.000 orang, serta kurang lebih sekitar 800 anggota baru yang masuk setiap tahun. ${ }^{8}$ Akun YISC Al-Azhar di YouTube mendapatkan banyak subscriber (6,97 ribu). jk ${ }^{9}$ Dengan besarnya jumlah peserta kajian tersebut membuktikan kajian di YISC cukup diminati oleh pelajar. Kajian Samara merupakan salah satu kajian yang diadakan oleh YISC Al-Azhar. ${ }^{10}$

Samara Series YISC Al-Azhar rutin diadakan setiap minggu di tahun 2018 yang Isi kajiannya adalah seputar cara mencari pasangan, menjalani hubungan sebelum menikah, kehidupan seputar rumah tangga, dan lainnya. ${ }^{11}$ Salah satu dainya seorang konsultan pernikahan \& keluarga islami yakni Ustaz Bendri Jaisyurrahman. Beliau adalah pendiri dan pembina Yayasan Langkah Kita yang sering menjadi narasumber di berbagai seminar, diskusi, dan sejumlah tayangan radio serta televisi. ${ }^{12}$ Pembawaannya yang santai, kocak, dan memberikan penjelasan dengan mudah membuat mitra dakwah fokus, sering tertawa, dan memberikan feed back berupa

\footnotetext{
9 "Samara series \# 1: "Kemanakah Kulabuhkan Hati ini"." Video YouTube, 1:45:53, dikirim oleh "YISC Al Azhar," Desember 20, 2020. https://youtu.be/eKuUiS50SeM.

${ }^{10}$ Redaksi, "YISC Youth Islamic Study Club," accessed December 4, 2020, http://www.alazhar.or.id/komunitas/yisc/.

11 "Samara series \# 5: "Sudah Terlanjur Cinta Ternyata Bukan Untukku"." Video YouTube, 1:15:07, dikirim oleh "YISC Al Azhar," Desember 20, 2020. https://youtu.be/Dsat6wG0ba8.

12 Redaksi, "Bendri Jaisyurrahman," accessed January 15, 2021, http://bendri.id.
} 
pertanyaan yang cukup banyak. ${ }^{13}$ Media yang digunakan adalah media daring dan luring yang sudah umum di kalangan remaja. Materi, dai, dan medianya dikelola agar tujuan kajian untuk membekali remaja tentang persiapan pernikahan tercapai. Hal ini, menunjukkan bahwa ada indikasi sebagian unsur dakwahnya telah dikelola sesuai dengan asumsi remaja.

Remaja yang memiliki kebutuhan untuk menjalin ikatan dengan lawan jenis akan memilih pasangan yang sesuai. Dalam faktanya ada muslim yang memiliki kriteria pasangan nonmuslim. ${ }^{14}$ Samara menjawab kebutuhan itu dengan materi terkait pemilihan pasangan. ${ }^{15}$ Ada pula remaja yang menjalani masa pacaran dengan melakukan tindakan seks pranikah. ${ }^{16}$ Samara memberikan jawaban terkait hukum Islam memandang seks pranikah dan bahayanya bagi remaja. ${ }^{17}$ Adanya kasus depresi remaja ketika menjalin hubungan, ${ }^{18}$ dijawab oleh Samara dengan berbagai tips islami. ${ }^{19}$ Kasuskasus itu membuktikan bahwa kajian samara mencoba memenuhi kebutuhan remaja terkait proses persiapan pernikahan. Remaja memiliki kondisi psikologis tersendiri yang seharusnya menjadi pijakan dalam penyelenggaraan sebuah kajian dakwah.

\footnotetext{
13 Samara series \# 5: "Sudah Terlanjur Cinta Ternyata Bukan Untukku"." Video YouTube, 1:15:07, dikirim oleh "YISC Al Azhar," Desember 20, 2020. https://youtu.be/Dsat6wG0ba8.

14 Ibid.

15 "Samara series \# 4: "Kamu, Kemungkinan Yang Aku Semogakan"." Video YouTube, 1:24:06, dikirim oleh "YISC Al Azhar," Desember 20, 2020. https://youtu.be/RtYifOuVN1s.

16 Alifia Satyana, "Kebutuhan Afiliasi Dan Perilaku Seksual Pranikah Pada Mahasiswa," Cognicia 8, no. 1 (2020):

162 ,

doi:https://doi.org/10.22219/COGNICIA.Vol8.No1.157 -168 .
}

Berdasarkan latar belakang pentingnya proses persiapan menikah dan adanya kajian Samara yang memiliki keunggulan, memunculkan pertanyaan bagaimana kajian dakwah pranikah Samara di YISC Al-Azhar dari perspektif psikologi remaja. Tujuannya untuk mengetahui kajian dakwah pranikah Samara Series YISC AI-Azhar dari perspektif psikologi remaja. Studi ini, mengambil tahun 2018-2019 karena pada hanya pada tahun itu YISC mengunggah kajian Samara yang temanya terkait persiapan menikah secara lengkap, terkait pengetahuan pernikahan, pemilihan pasangan, membina hubungan, dan menyiapkan pernikahan. Kajian dakwah dari Samara akan dikupas dan didekati dengan psikologi remaja terkait persiapan menikah. Psikologi remaja terkait persiapan menikah terkait kebutuhan remaja menuju pernikahan, masalah yang dihadapi, atau persepsi lain remaja terkait pernikahan. Perspektif psikologi remaja terkait persiapan menikah ini dijadikan pisau analisis dalam studi ini, karena remaja sebagai mad'uw dari kajian Samara, sehingga kajian ini harus menyesuaikan dengan sasarannya.

Studi terdahulu yang membahas tentang hal pranikah, banyak menyasar calon pengantin dan subjek studinya adalah KUA yang itu perspektifnya adalah pendidikan Islam. Studi yang membahas kegiatan pranikah

\footnotetext{
17 Samara series \# 4: "Kamu, Kemungkinan Yang Aku Semogakan"." Video YouTube, 1:24:06, dikirim oleh "YISC Al Azhar," Desember 20, 2020. https://youtu.be/RtYifOuVN1s

${ }^{18}$ Agus M, Sri, AA, “Hubungan Kegagalan Cinta Dengan Terjadinya Kejadian Depresi Pada Remaja (Suatu Studi Kelas Sebelas Di SMAN 3 Bojonegoro)," Jurnal Asuhan Kesehatan 7, no. 2 (2016): 23 http://ejournal.rajekwesi.ac.id/index.php/jurnalpenelitian-kesehatan/article/view/133/115.

19 "Samara series \# 5: "Sudah Terlanjur Cinta Ternyata Bukan Untukku"." Video YouTube, 1:15:07, dikirim oleh "YISC Al Azhar," Desember 20, 2020 https://youtu.be/Dsat6wG0ba8.
} 
dalam perspektif dakwah dan menjadikan remaja sebagai objek studi sangat jarang ditemui. Contohnya saja, studi Bimbingan Pranikah bagi Calon Pengantin KUA Kecamatan Cimanggung, Sumedang, ${ }^{20}$ Pembinaan Pranikah dalam Peningkatan Pemahaman Keagamaan Calon Pengantin di KUA Kecamatan Sleman, ${ }^{21}$ dan Kursus pranikah: Konsep dan Implementasinya (Studi Komparatif antara BP4 KUA Kecamatan Pontianak Timur dengan GKKB Jemaat Pontianak). ${ }^{22}$ Dari paparan di atas, dapat disimpulkan belum ditemuinya studi tentang kajian persiapan menikah untuk kalangan remaja dari perspektif psikologi remaja.

Studi ini, diharapkan mampu memberikan tambahan wawasan keilmuan baru dalam pengelolaan kajian dakwah remaja dalam persiapan pernikahan. Kajian dakwah ini terkait tujuan, materi, dai, metode, dan media. Pengetahuan terkait kajian dakwah perspektif psikologi remaja bisa menjadi masukan dalam proses memanajemen dakwah untuk remaja. Di samping itu, bisa memberikan inspirasi bagi para pegiat dakwah remaja terkait masalah-masalah remaja yang sedang menuju pernikahan dan solusi yang diberikan.

${ }^{20}$ Alifah Nurfauziyah, "Bimbingan Pranikah Bagi Calon Pengantin Dalam Mewujudkan Keluarga Sakinah," Jurnal Bimbingan, Penyuluhan, Konseling, Dan Psikoterapi Islam 5, no. 4 (2017): 449, doi:https://doi.org/10.15575/irsyad.v5i4.

21 Samsul Alam, "Pembinaan Pranikah Dalam Peningkatan Pemahaman Keagamaan Calon Pengantin Di KUA Kecamatan Sleman," G-Couns: Jurnal Bimbingan Dan Konseling 4, no. 1 (2020): 25, doi:10.31316/g.couns.v4i1.447.

${ }^{22}$ Muhammad Lutfi Hakim, "Kursus Pra-Nikah: Konsep Dan Implementasinya (Studi Komparatif Antara BP4 KUA KEC. Pontianak Timur Dengan GKKB Jemaat Pontianak)," Al-Maslahah Jurnal Ilmu Syariah 13, no. 2 (2017): 191, doi:10.24260/almaslahah.v13i2.924.
Jenis studi ini adalah kualitatif deskriptif. Teknik penggalian data yang akan digunakan pada studi ini adalah dokumentasi. Sumber data dalam studi ini, adalah situs resmi dari YISC Al-Azhar yang terdiri dari website, ${ }^{23}$ Instagram, ${ }^{24}$ dan YouTube. ${ }^{25}$ Video YouTube yang akan dianalisis berjumlah 9 video yang diunggah tahun 2018-2019 tentang proses penyelenggaraan samara yang bertema persiapan pernikahan. Analisis data dalam studi ini, menggunakan model Miles dan Huberman yaitu melalui proses reduksi data, penyajian data dan penarikan kesimpulan serta pengujian ulang atau verifikasi. ${ }^{26}$ Data terkait kajian dakwah Samara dikumpulkan lalu dikelompokkan berdasar variabel yang berkaitan dengan studi ini. Lalu dianalisis dengan menggunakan teori psikologi remaja terkait persiapan menikah, sehingga bisa menunjukkan temuan terkait dakwah pada remaja yang melakukan persiapan menikah. Teori dakwah yang digunakan yakni teori unsur dakwah oleh Ali Aziz. Teori ini menyatakan bahwa unsur dakwah terdiri dari pendakwah, mitra, materi, metode, dan media dakwah. Semua unsur tersebut mengarah pada tujuan dakwah. ${ }^{27}$ Psikologi remaja yang dijadikan pisau analisa adalah psikologi terkait persiapan menikah.

\footnotetext{
${ }^{23}$ Redaksi, "YISC Youth Islamic Study Club."

24 Instagram @yisc_alazhar, Instagram post, April 15, 2021,

http://instagram.com/yisc_alazhar?utm_medium =co py_link.

25 "Samara series \# 1: "Kemanakah Kulabuhkan Hati ini"." Video YouTube, 1:45:53, dikirim oleh "YISC Al Azhar," Desember 20, 2020. https://youtu.be/eKuUiS50SeM.

${ }^{26}$ Adrianus Sutopo, Ariseto Hadi and Arief, Terampil Mengolah Data Kualitatif Dengan NVINO (Jakarta: Kencana, 2010), 10.

27 Ali Aziz, Ilmu Dakwah (Jakarta: Prenadamedia, 2016), 204.
} 


\section{Dakwah}

Dakwah adalah kegiatan yang bertujuan melakukan perubahan positif dalam diri manusia yakni pada tingkat keimanannya dengan standar/ukuran baik buruk berdasar Al-Qur'an dan hadis. Secara ringkas, dakwah adalah kegiatan peningkatan iman menurut syariat Islam. ${ }^{28}$ Dari uraian tersebut maka makna dakwah adalah kegiatan untuk mengubah perilaku keimanan berdasar standar Al-Qur'an dan hadis.

Tujuan dakwah dapat diibaratkan sebagai sebuah mimpi atau cita-cita yang akan dicapai dai. Tujuan dapat dibagi menjadi 2 yakni tujuan jangka panjang/umum dan jangka pendek/khusus. Tujuan jangka panjang/umum yaitu:

menjadikan/mengajak semua orang untuk beribadah dalam arti menjalankan perintah Allah dan Rasul-Nya dan menjauhi segala larangan-Nya; (2) menciptakan rahmat dan berkah dalam kehidupan di dunia, umat manusia dan serta makhluk Allah di alam semesta; dan (3) agar manusia mendapatkan kebahagiaan hidup di dunia dan akhirat. ${ }^{29}$

Tujuan jangka pendek/khusus yaitu: (1) membina mental dan keimanan para mualaf yang baru masuk Islam atau yang masih lemah keimanannya; (2) meningkatkan keimanan dan ketakwaan umat Islam yang telah cukup kuat keimanannya; (3) mendidik dan mengajarkan anak-anak agar dapat mengembangkan potensinya sesuai dengan jalan Allah dan sebagai khalifah fil ard; dan (4) mengajak kepada umat manusia yang belum meyakini ajaran Islam agar meyakini dan menjalankan ajaran Islam. ${ }^{30}$

28 Ibid., 19.

29 Ropingi el Ishaq, Pengantar Ilmu Dakwah: Studi Komprehensif Dakwah Dan Teori Ke Praktik (Malang: Madani, 2016), 40-47.
Unsur dakwah yang kedua yakni pendakwah/dai. Pendakwah adalah orang yang melakukan dakwah. ${ }^{31}$ Kompetensi yang harus dimiliki dai agar dakwah berjalan sukses yakni memiliki: (a) kemampuan berkomunikasi agar pesan yang disampaikan mudah diterima mad'uw; (b) kemampuan penguasaan diri, jangan sampai seorang dai memperlihatkan sikap yang tidak baik;( c) kemampuan pengetahuan psikologi untuk menghadapi mad'uw-nya yang memiliki beragam sikap; d) kemampuan pengetahuan kependidikan, entah teknik, metode, atau strateginya; (e) kemampuan pengetahuan di bidang pengetahuan umum; (f) kemampuan di bidang Al-Qur'an dan hadis dalam pembacaannya dan pemaknaannya; dan (g) kemampuan di bidang ilmu agama secara integral. ${ }^{32}$

Unsur dakwah yang ketiga adalah mad'uw/mitra dakwah. Menurut Ali Aziz, dari sudut sosio-antropologis, mad'uw dapat dibedakan dari status sosial, bentuk kelompok, dan sistem budaya. Mad'uw bisa sebagai individu dan kelompok. Bisri Mustofa dalam Ali Aziz, membuat tujuh status manusia terkait dakwah yakni: (1) masyarakat awam; (2) masyarakat pelajar dan mahasiswa; (3) pejabat pemerintah; (4) golongan non muslim; (5) pemimpin golongan/ketua suku; (6) kelompok hartawan; dan (7) para ulama dan cendekiawan. Status mad'uw harus menjadi perhatian bagi pendakwah, karena strategi dakwah dapat berbeda manakala mad'uw

30 lbid.

${ }^{31}$ Aziz, Ilmu Dakwah, 216.

32 Samsul Munir Amin, Ilmu Dakwah (Jakarta: Amzah, 2009), 79-85. 
yang dihadapi memiliki status yang berbeda. ${ }^{33}$

Unsur dakwah berikutnya adalah pesan dakwah. Menurut Ali Aziz, istilah pesan dakwah lebih tepat dibanding dengan materi dakwah. Pesan dakwah adalah isi dakwah berupa kata, gambar, lukisan, dan sebagainya yang diharapkan dapat memberikan pemahaman bahkan perubahan sikap dan perilaku mad'uw. ${ }^{34}$ Pesan dakwah pada garis besarnya terbagi menjadi dua yakni pesan utama (Al-Qur'an dan hadis) dan pesan tambahan/penunjang (selain Al-Qur'an dan hadis). Macamnya yakni ayat-ayat Al-Qur'an, hadis Nabi saw., pendapat para sahabat Nabi saw., pendapat para ulama, hasil studi ilmiah, kisah dan pengalaman teladan, berita dan peristiwa, karya sastra, dan karya seni. ${ }^{35}$

Menurut Faizah dalam Rahmatullah, agar pesan dakwah yang disampaikan bisa diterima dengan baik, maka pengetahuan tentang mad'uw dengan segala karakternya sangat penting. Secara psikologis manusia sebagai mad'uw dapat dibedakan oleh berbagai aspek, yaitu: (1) Sifat-sifat kepribadian yaitu sifat-sifat manusia seperti penakut, pemarah, suka bergaul, peramah, sombong, dan sebagainya; (2) Inteligensi yaitu aspek kecerdasan seseorang yang mencakup kewaspadaan, kemampuan belajar, kecepatan berpikir, kesanggupan untuk mengambil keputusan yang tepat dan cepat, kepandaian menangkap dan

${ }^{33}$ Aziz, Ilmu Dakwah, 284.

34 Ibid., 318.

35 Ibid., 318-330.

36 Rahmatullah Rahmatullah, "Analisis Penerapan Metode Dakwah Berdasarkan Karakteristik Mad'u Dalam Aktivitas Dakwah," Jurnal Mimbar: Media Intelektual Muslim Dan Bimbingan Rohani 2, no. 1 (2016): 59, doi:10.47435/mimbar.v2i1.286. mengolah kesan-kesan atau masalah, dan kemampuan mengambil kesimpulan; (3) Pengetahuan (knowledge); (4) Keterampilan (skill); (5) Nilai-nilai (values); dan (6) Peranan (roles). ${ }^{36}$ Jalaluddin Rakhmat dalam Renel menyatakan bahwa setiap mad'uw kecenderungan memiliki kebutuhan pesan dakwah sesuai dengan kebutuhan mad'uw. Hal ini berpijak dari use and gratification theory Blumer. Dai perlu memahami dan merasakan kebutuhan mad'uw dari problematika sosial yang dihadapi. ${ }^{37}$ Kesimpulannya pesan dakwah harus disesuaikan dengan aspek kedirian dari mad'uw.

Unsur dakwah berikutnya adalah metode dakwah. Metode dakwah adalah tata cara menjalankan dakwah agar mencapai tujuan dakwah yang telah direncanakan. ${ }^{38}$ Ada tiga macam metode dakwah. Pertama, metode bil hikmah. Berdasar dari berbagai ahli tafsir, Ali Aziz memaknai al-hikmah adalah perkataan yang sempurna, yakni dalil yang menjelaskan kebenaran dan menjauhkan keraguan atau argumentasi yang pasti dan berfaedah untuk akidah yang diyakini. Selain itu, Quraish Shihab dalam Aziz, memaknai alhikmah sebagai "yang paling utama dari segala sesuatu, baik pengetahuan atau perbuatan. la bebas dari kesalahan dan mendatangkan kemaslahatan yang besar. ${ }^{39}$ Dakwah bi al-hikmah merupakan penyeruan atau pengajakan dengan cara bijak, filosofis, argumentatif, dilakukan dengan adil, penuh kesabaran dan ketabahan, sesuai dengan

37 Baiti Renel, "Materi Dakwah Dan Kebutuhan Mad'uw (Studi Kasus Pada Majelis Taklim Nurul Qulub Di Kecamatan Baguala Kota Ambon)" (Universitas Islam Negeri (UIN) Alauddin Makasar, 2012).

38 Ishaq, Pengantar IImu Dakwah: Studi Komprehensif Dakwah Dan Teori Ke Praktik, 104.

${ }^{39}$ Aziz, Ilmu Dakwah, 392. 
Risalah Al-Nubuwwah dan ajaran Al-Quran atau wahyu Illahi. ${ }^{40}$

Kedua, metode mau'idzatil hasanah. Menurut Wahidin Saputra dalam Rahmatullah, mauidzah hasanah diklasiifikasikan dalam beberapa bentuk, yaitu: (1) Nasihat atau petuah; (2) Bimbingan, pengajaran (pendidikan); (3) Kisah-kisah; (4) Kabar gembira dan peringatan; (5) Wasiat (pesan-pesan positif). ${ }^{41}$ Arifudddin dalam Rahmatullah merumuskan karakteristik metode dakwah mauidzah hasanah, sebagai berikut: (1) Bentuk nasihat berupa pernyataan yang disampaikan melalui bahasa lisan maupun tulisan; (2) Menggunakan bahasa persuasif dengan bahasa simpati mudah menyentuh hati dan menggugah kesadaran pihak mad'uw untuk melakukan perbuatan yang makruf dan meninggalkan perbuatan mungkar; (3) Dai memperlihatkan sikap lemah-lembut (layyin) atau penuh kasih sayang; (4) Disertai argumen-argumen yang logis, menggembirakan berupa hal-hal kenikmatan. Begitu pula di dalamnya dikemukakan izzar (informasi yang menakutkan) yang berupa siksaan sangat dahsyat dalam neraka. Dengan tujuan mendorong mereka melakukan perbuatan yang baik dan memberi daya potensi kepada mereka untuk meninggalkan perbuatanperbuatan yang jelek. ${ }^{42}$

\footnotetext{
${ }^{40}$ Aliyudin, "Prinsip-Prinsip Metode Dakwah Menurut Al-Quran," IImu Dakwah: Academic Journal for Homiletic Studies 4, no. 15 (2010): 190, doi:10.15575/idajhs.v5i16.360.

${ }^{41}$ Rahmatullah, "Analisis Penerapan Metode Dakwah Berdasarkan Karakteristik Mad'u Dalam Aktivitas Dakwah," 66.

42 Ibid., 66-67.

${ }^{43}$ Ishaq, Pengantar Ilmu Dakwah: Studi Komprehensif Dakwah Dan Teori Ke Praktik, 122.
}

Ketiga, dakwah bi al-mujadalah adalah dakwah dengan cara melakukan perdebatan/perbantahan kepada mad'uw. Caranya dengan menggunakan logika dan retorika yang baik, atau dengan menyebarkan gagasan ke media massa secara perlahan dan bahkan tidak terasa tetapi memiliki pengaruh mendalam kepada masyarakat. ${ }^{43}$

Menurut Ali Aziz, metode dakwah harus menyesuaikan dengan kondisi mad'uw. Metode dakwah harus dapat menggugah hati mad'uw. ${ }^{44}$ Metode bi al-hikmah sebagai metode yang utama secara garis besar diarahkan kepada masyarakat cendikiawan atau khawas, penerapan metode mauidzah hasanah kepada masyarakat pertengahan dan metode mujadalah untuk masyarakat awam (masyarakat yang masih dikungkung oleh tradisi jahiliah yang terkadang dengan kesombongannya melakukan kebatilan secara terang-terangan). ${ }^{45}$ Sedangkan menurut Syekh M. Abduh dalam Nurbini menyimpulkan bahwa ketika menghadapi orang cerdik pandai, yang berpikir kritis dan akademis maka dihadapi dengan bil hikmah. Orang awam dan kebanyakan tanpa latar belakang pendidikan tinggi, maka cukup dengan mau'idzatil hasanah. Sedangkan orang-orang yang bukan cerdik cendekiawan, tetapi juga bukan termasuk kalangan awam, maka dihadapi dengan mujadalah. ${ }^{46}$

\footnotetext{
${ }^{44}$ Aziz, Ilmu Dakwah, 347-348.

${ }^{45}$ Rahmatullah, "Analisis Penerapan Metode Dakwah Berdasarkan Karakteristik Mad'u Dalam Aktivitas Dakwah," 55.

${ }^{46}$ Nurbini, "Bahasa Dakwah Untuk Kalangan Remaja Terpelajar," Jurnal Dakwah XI, no. 1 (2011): 119, http://ejournal.uin-

suka.ac.id/dakwah/jurnaldakwah/article/download/3 99/378.
} 
Unsur dakwah yang terakhir adalah media dakwah. Media dakwah adalah alat yang menjadi perantara penyampaian pesan dakwah kepada mad'uw. ${ }^{47}$ Jenis media dakwah yakni media auditif, visual, dan audio visual. ${ }^{48}$ Media dakwah dapat berfungsi secara efektif bila ia dapat menyesuaikan diri dengan pendakwah, pesan dakwah, mitra dakwah, metode dakwah, dan logistik dakwah. ${ }^{49}$

Menurut Ali Aziz, pendakwah, metode, pesan, dan media dakwah harus menyesuaikan dengan kondisi mad'uw. Pendekatan dakwah yang terpusat pada mad'uw memfokuskan unsur-unsur dakwah pada upaya penerimaan mad'uw. Siapakah pendakwah yang cocok bagi mad'uw dengan tipologi tertentu; manakah pesan dakwah yang paling dibutuhkan mad'uw; serta metode dan media dakwah yang bagaimanakah yang dapat menggugah hati mad'uw. $^{50}$

\section{PSIKOLOGI REMAJA}

Dalam studi ini, perlu membatasi asumsi remaja dan kondisi psikologisnya untuk dijadikan pisau analisis kualitas unsur dakwah kajian Samara. Hurlock dalam Khorilul dan M. Farid membagi fase remaja menjadi masa remaja awal dengan usia antara 13-17 tahun dan masa remaja akhir usia antara 17-18 tahun. $^{51}$ Sedangkan Thornburg dalam Tetty dan Yolanda

\footnotetext{
${ }^{47}$ Aziz, Ilmu Dakwah, 404.

48 Ibid., 410.

49 Ibid., 428.

50 Ibid., 347-48.

${ }^{51}$ Khoirul Bariyyah Hidayati and . M Farid, "Konsep Diri, Adversity Quotient Dan Penyesuaian Diri Pada Remaja," Persona:Jurnal Psikologi Indonesia 5, no. 02 (2016): 137, doi:10.30996/persona.v5i02.730.
}

melakukan penggolongan remaja menjadi 3 tahap, yaitu remaja awal (usia 13-14 tahun), remaja tengah (usia 15-17 tahun) dan remaja akhir usia 18-21 tahun. ${ }^{52}$ Desmita dalam Febri juga menyatakan penggolongan remaja seperti Thornburg. ${ }^{53}$ Dalam studi ini, sasaran dakwah kajian samara adalah remaja muslim. ${ }^{54}$

Gunarsa dan Mappiare dalam Khamim menyatakan bahwa remaja di masa awal, madya, dan akhir memiliki ciri khas masingmasing. Masa remaja awal biasanya duduk di bangku SMP, dengan ciri-ciri: (1) tidak stabil keadaannya, lebih emosional; (2) mempunyai banyak masalah; (3) masa yang kritis; (4) mulai tertarik pada lawan jenis; (5) munculnya rasa kurang percaya diri; dan (6) suka mengembangkan pikiran baru, gelisah, suka berkhayal dan suka menyendiri. Masa remaja madya (pertengahan) biasanya duduk di bangku SMA dengan ciri-ciri: (1) sangat membutuhkan teman; (2) cenderung bersifat narsistik/kecintaan pada diri sendiri; (3) berada dalam kondisi keresahan dan kebingungan, karena pertentangan yang terjadi dalam diri; (4) berkenginan besar mencoba segala hal yang belum diketahuinya; dan (5) keinginan menjelajah ke alam sekitar yang lebih luas. Masa remaja akhir ditandai dengan ciri-ciri: (1) aspekaspek psikis dan fisiknya mulai stabil; (2) meningkatnya berfikir realistis, memiliki sikap pandang yang sudah baik; (3) lebih matang dalam cara menghadapi masalah; (4) ketenangan emosional bertambah, lebih

52 Tetty Rihardini and Yolanda S, "Persepsi Remaja Tentang Perilaku Seks Pranikah Di SMA X," EMBRIO 1, no. 1 (2012): 6, doi:10.36456/embrio.vol1.no0.a1190.

53 Febri Fajarini and Nuristighfari Masri Khaerani, "Kelekatan Aman, Religiusitas, Dan Kematangan Emosi Pada Remaja," Jurnal Psikologi Integratif 2, no. 1 (2014): 22, doi:https://doi.org/10.14421/jpsi.2014.\%25x.

${ }^{54}$ Redaksi, "Latar Belakang." 
mampu menguasai perasaan; (5) sudah terbentuk identitas seksual yang tidak akan berubah lagi; dan (6) lebih banyak perhatian terhadap lambang-lambang kematangan. ${ }^{55}$

Menurut Sidik Jatmika dalam Khamim, ${ }^{56}$ masa remaja merupakan masa-masa sulit bagi remaja dan orang tua karena ada perilaku-perilaku khusus. Pertama, remaja mulai menyampaikan kebebasannya dan haknya untuk mengemukakan pendapatnya sendiri. Kedua, remaja lebih mudah dipengaruhi oleh teman-temannya daripada orang tua. Ketiga, remaja mengalami perubahan fisik. Perasaan seksual yang mulai muncul bisa menakutkan, membingungkan dan menjadi sumber perasaan salah dan frustrasi. Keempat, remaja sering menjadi terlalu percaya diri dan disertai emosinya yang biasanya meningkat, mengakibatkan sulit menerima nasihat orang tua.

Menurut Zakiah Daradjat, sikap keagamaan remaja yakni yang pertama percaya secara ikut-ikutan. Remaja mengkoreksi kembali kepercayaan dan ajaran agama dari waktu kecil, akhirnya menjadi ragu-ragu pada agamanya, bahkan menjadi anti pada agama. Kedua, percaya dengan kesadaran. Remaja memiliki kepercayaan lebih fundamental, ingin membuktikan

55 Khamim Zarkasih Saputro, "Memahami Ciri Dan Tugas Perkembangan Masa Remaja," Aplikasia: Jurnal Aplikasi Ilmu-IImu Agama 17, no. 1 (2018): 29, doi:10.14421/aplikasia.v17i1.1362.

56 Ibid., 26.

57 Syaiful Hamali, "Syaiful Hamali, Karakteristik Keberagamaan," Karakteristik Keberagaman Remaja Dalam Perspektif Psikologi 11, no. 1 (2016): 10-11, doi:https://doi.org/10.24042/ajsla.v11i1.1438.

${ }^{58}$ Akiko. et al. Susanto, Tatut. Kimura, Rumiko. Tsuda, “Persepsi Remaja Dalam Perencanaan Keluarga Di Daerah Rural Dan Urban Kabupaten Jember, Provinsi Jawa Timur, Indonesia," Jurnal Keluarga Berencana 1, no. 1 (2016): kepercayaan yang secara riil, ingin menghubungkan dirinya dengan Tuhan. ${ }^{57}$

Terkait dengan persiapan pernikahan, remaja memiliki presepsi dan keinginan tersendiri. Remaja akan menjalin hubungan sebelum menikah dengan cara bertunangan sebagai upaya saling mengenal pasangan. Pernikahan akan berlanjut pada usia di atas 20 tahun dengan tujuan membangun dan membina sebuah keluarga.$^{58}$ Kriteria utama pemilihan pasangan hidup yang akan dipertimbangan oleh remaja, terkait dengan usia, suku, status pernikahan, pendapatan dan pekerjaan. Remaja akan memilih pasangan hidup yang memiliki suku sama atau memiliki kedekatan secara budaya. Rentang pendidikan pasangan diharapkan antara strata 1-3 dengan pekerjaan sebagai tenaga ahli, wiraswasta hingga TNI/Kepolisian. ${ }^{59}$ Ada juga remaja yang tidak mempertimbangkan terkait dengan agama, dalam arti tidak selalu memiliki agama yang sama. ${ }^{60}$ Ahmad Nurcholish menjelaskan bahwa jumlah pasangan pernikahan beda agama sejak tahun 2004 hingga 2012 tercatat sudah mencapai 1.109 pasangan. Paling besar pasangan nikah beda agama itu adalah antara Islam dan Kristen, Ialu Islam dan Katolik, Ialu Islam dan Hindu, Ialu Islam dan Budha dan paling sedikit adalah Kristen dan budha. ${ }^{61}$ Orang tua tidak terlibat dalam

http://repository.unej.ac.id/handle/123456789/8365 6.

${ }^{59}$ Rizqi Maulida Amalia and Muhammad Yudi Ali Akbar, "Konseling Islam Perannya Bagi Pemilihan Pasangan Dan Kesiapan Pernikahan," JURKAM: Jurnal Konseling Andi Matappa 1, no. 2 (2017): 129 doi:10.31100/jurkam.v1i2.58.

$60 \mathrm{lbid}$.

${ }^{61}$ Cholis Akbar, "Sejak 2004-2011 Ada 1190 Pernikahan Beda Agama," accessed August 27, 2021 https://www.hidayatullah.com/berita/nasional/read/ 2012/03/31/58025/sejak-2004-2011-ada-1190pernikahan-beda-agama.html. 
pemilihan secara personal pasangan, namun terlibat dalam melihat latar belakang keluarga calon pasangan hidup anaknya. ${ }^{62}$

Berdasarkan hasil survei kesehatan reproduksi remaja, remaja Indonesia pertama kali pacaran pada usia 15-17 tahun. Sekitar 33,3\% remaja perempuan dan 34,5\% remaja laki-laki yang berusia 15-19 tahun mulai berpacaran pada saat mereka belum berusia 15 tahun. ${ }^{63}$ Dalam proses pacaran, timbul kasus seks pranikah. Di Indonesia, sekitar $25 \%$ - 51\% remaja telah berhubungan seks pranikah. ${ }^{64}$ Penyebab dari seks pranikah bisa bermacam-macam. Hasil penelitian Alifia, menunjukkan bahwa kebutuhan afiliasi memiliki korelasi positif dengan perilaku seksual pranikah. ${ }^{65}$ Selain itu, bisa disebabkan karena konsumsi hal-hal terkait pornografi. ${ }^{66}$ Dari penelitian Anis, terdapat hubungan yang sangat signifikan antara harga diri dan religiusitas dengan perilaku seksual pranikah remaja. ${ }^{67}$ Selain adanya kasus seks pranikah, remaja juga mengalami masalah patah hati dalam proses memilih pasangan. Menurut Santrock dalam Sri, remaja mengalami depresi karena terjadi konflik dengan pacar, kemudian lari ke narkoba, minuman keras, pergaulan seks bebas, serta masih banyak kasus lain. ${ }^{68}$

62 Anna Armeini Rangkuti and Devi Oktaviani Fajrin, "Preferensi Pemilihan Calon Pasangan Hidup Ditinjau Dari Keterlibatan Ayah Pada Anak Perempuan," JPPP Jurnal Penelitian Dan Pengukuran Psikologi 4, no. 2 (2015): 63, doi:10.21009/JPPP.042.03.

63 Windhu. Ohee, Christine. Purnomo, "Pengaruh Status Hubungan Berpacaran Terhadap Perilaku Pacaran Berisiko Pada Mahasiswa Perantau Asal Papua Di Kota Surabaya," The Indonesian Journal of Public Health 13, no. 2 (2019): 269, doi:10.20473/ijph.v13i2.2018.269-287.

${ }^{64}$ Komang Yuni Rahyani et al., "Perilaku Seks Pranikah Remaja," Kesmas: National Public Health Journal 7, no. 4 (2012): 181, doi:10.21109/kesmas.v7i4.53.

65 Satyana, "Kebutuhan Afiliasi Dan Perilaku Seksual Pranikah Pada Mahasiswa," 162.

\section{Profil YISC Al-Azhar}

YISC Al-Azhar adalah organisasi kepemudaan masjid pertama yang berdiri di tanah air pada 16 Mei 1971 di Jakarta. Organisasi ini didirikan oleh orang-orang yang prihatin dan terpanggil untuk memperbaiki keadaan generasi muda Islam yang mengalami kemerosotan moral dan mental yang semakin jauh dari agama Islam dan cita-cita bangsa Indonesia. ${ }^{69}$ YISC Al-Azhar memiliki tujuan untuk membina generasi muda agar menjadi generasi yang bertanggung jawab, mempertahankan, dan memperjuangkan nilai-nilai Islam dan kesejahteraan umat. YISC AI-Azhar memiliki visi untuk menjadi komunitas belajar yang ber-akhlakul karimah dengan berlandaskan Al-Qur'an dan sunah. YISC Al-Azhar memiliki misi sebagai berikut: a) Da'a llallah (berdakwah di jalan Allah); b) Amila Shalihan (melakukan amal shaleh); dan c) Innani minal Muslimin (menegakkan kepribadian muslim). ${ }^{70}$

Salah satu kajian yang diselenggarakan oleh YISC Al-Azhar adalah Kajian Samara. ${ }^{71}$ Isi kajiannya adalah seputar cara mencari pasangan, menjalani hubungan sebelum menikah, kehidupan seputar rumah tangga, dan lainnya. ${ }^{72}$ Dengan kata lain tema-tema

66 Galih Haidar and Nurliana Cipta Apsari, "Pornografi Pada Kalangan Remaja," Prosiding Penelitian Dan Pengabdian Kepada Masyarakat 7, no. 1 (2020): 140, doi:10.24198/jppm.v7i1.27452.

${ }^{67}$ Anis Rosidah, "Religiusitas, Harga Diri, Dan Perilaku Seksual Pranikah Remaja," Jurnal Psikologi 7, no. 2 (2012):

592 ,

https://jurnal.unmer.ac.id/index.php/jpt/article/view/ 197/68.

68 M, Sri, AA, "Hubungan Kegagalan Cinta Dengan Terjadinya Kejadian Depresi Pada Remaja (Suatu Studi Kelas Sebelas Di SMAN 3 Bojonegoro)," 23.

${ }^{69}$ Redaksi, "YISC Al-Azhar."

${ }^{70}$ Ibid.

${ }^{71}$ Redaksi, "YISC Youth Islamic Study Club."

72 "Samara series \# 5: "Sudah Terlanjur Cinta Ternyata Bukan Untukku"." Video YouTube, 1:15:07, dikirim oleh 
yang diangkat terkait dalam kegiatan pranikah. Kajian ini dipandu oleh Ustaz Elvin Sasmita di awal series. ${ }^{73}$ Series ke-4 dan seterusnya diisi oleh Ustaz Bendri Jaiusyurrahman. ${ }^{74}$ Metode yang digunakan oleh Ustaz Elvin Sasmita dominan menggunakan metode ceramah. ${ }^{75}$ Begitu pula dengan Ustaz Bendri. ${ }^{76}$

\section{Kajian Dakwah Samara YISC Al-Azhar dari Perspektif Psikologi Remaja}

YISC Al-Azhar mengadakan beberapa kajian islami, salah satunya adalah Kajian Samara yang membahas terkait kegiatan pranikah. ${ }^{77}$ Kajian ini akan dikupas dari perspektif psikologi remaja. Berdasarkan uraian landasan teori di atas maka dapat dianalisis beberapa aspek/unsur dakwah berikut ini.

Pertama, unsur tujuan dakwah. YISC bertujuan untuk membina generasi muda agar menjadi generasi yang bertanggung jawab, mempertahankan, dan memperjuangkan nilai-nilai Islam dan kesejahteraan umat. $^{78}$ Nilai-nilai Islam yang dibentuk adalah nilai tentang proses menyiapkan pernikahan yang orientasinya takwa. Hal ini disampaikan saat Samara series ke-1, "Kemanakah Kulabuhkan Hati

"YISC Al Azhar," Desember 20, 2020. https://youtu.be/Dsat6wG0ba8.

73 "Samara series \# 1: "Kemanakah Kulabuhkan Hati ini"." Video YouTube, 1:45:53, dikirim oleh "YISC Al Azhar," Desember 20, 2020. https://youtu.be/eKuUiS50SeM.

74 "Samara series \# 4: "Kamu, Kemungkinan Yang Aku Semogakan"." Video YouTube, 1:24:06, dikirim oleh "YISC Al Azhar," Desember 20, 2020. https://youtu.be/RtYifOuVN1s.

75 "Samara series \# 1: "Kemanakah Kulabuhkan Hati ini"." Video YouTube, 1:45:53, dikirim oleh "YISC Al Azhar," Desember 20, 2020. https://youtu.be/eKuUiS50SeM

76 "Samara series \# 4: "Kamu, Kemungkinan Yang Aku Semogakan"." Video YouTube, 1:24:06, dikirim oleh ini?". Jika dibenturkan dengan teori maka tujuan dari kajian masuk tujuan jangka pendek karena kajian ini hanya untuk remaja yang belum menikah.

Menurut penuturan dai, tanpa dibekali dengan wawasan dan keyakinan terkait pernikahan yang orientasinya takwa maka sangat mungkin akan berujung pada pernikahan yang malah menjauhkan diri dari takwa, misalkan nikah dengan pasangan tidak seiman sehingga keluar dari Islam, tidak melakukan proses taaruf dengan benar, tidak menyiapkan bekal dalam pernikahan dengan baik (ilmu, mental, ekonomi, dan lainnya), terjerumus dalam sikap tercela sebelum menikah (misal free sex, dan lainnya). ${ }^{79}$ Pada kenyataannya, remaja saat melakukan persiapan menikah, memang ada yang keluar dari norma Islam. Ada kasus free sex $^{80}$ kecanduan pornografi, ${ }^{81}$ dan tidak mendasarkan pada keimanan ketika memilih pasangan. ${ }^{82}$ Adanya persepsi terkait kriteria pemilihan pasangan juga mempengaruhi nantinya pernikahan membawa ketakwaan atau tidak. Kriteria utama pemilihan pasangan hidup oleh remaja, terkait dengan usia, suku, status pernikahan, pendapatan dan

\footnotetext{
"YISC Al Azhar," Desember 20, 2020. https://youtu.be/RtYifOuVN1s.

77 "Samara series \# 1: "Kemanakah Kulabuhkan Hati ini"." Video YouTube, 1:45:53, dikirim oleh "YISC Al Azhar," Desember 20, 2020. https://youtu.be/eKuUiS50SeM.

78 Redaksi, "YISC Al-Azhar."

79 "Samara series \# 1: "Kemanakah Kulabuhkan Hat ini"." Video YouTube, 1:45:53, dikirim oleh "YISC Al Azhar," Desember 20, 2020 https://youtu.be/eKuUiS50SeM.

${ }^{80}$ Rahyani et al., "Perilaku Seks Pranikah Remaja," 181.

81 Haidar and Apsari, "Pornografi Pada Kalangan Remaja," 140.

${ }^{82}$ Amalia and Ali Akbar, "Konseling Islam Perannya Bagi Pemilihan Pasangan Dan Kesiapan Pernikahan," 129.
} 
pekerjaan. ${ }^{83}$ Jadi hal ini, menunjukkan bahwa tujuan kajian samara sesuai dengan psikologi remaja, mencoba menjawab permasalahan remaja dalam persiapan menikah.

Kedua, unsur pendakwah di Kajian Samara. Dai yang menjadi pengisi adalah Ustaz Bendri Jaiusyurrahman dan Ustaz Elvin Sasmita. ${ }^{84}$ Ustaz Bendri lahir di Jakarta tahun 1981. Beliau memiliki Instagram yang memuat pesan tentang keluarga, pernikahan, anak yakni @ajobendri. ${ }^{85}$ Channel YouTube milik Ustaz Bendri adalah Langkah Kita. ${ }^{86}$ Beliau juga pendiri dan pembina dari Yayasan Langkah Kita. Yayasan Langkah Kita ingin mewujudkan visinya dalam mengambil peranan aktif untuk mengembangkan kualitas keluarga Indonesia serta menjadikan anak \& remaja Indonesia kuat, benar, dan baik. ${ }^{87}$ Pendidikannya di Mahad Al Hikmah Jakarta, FISIP UI, dan Mahad Utsman bin Affan Jakarta. Selain sebagai penulis buku, juga sebagai konselor keluarga dan pernikahan serta pengisi seminar, diskusi, serta sejumlah tayangan radio dan televisi. ${ }^{88}$ Sedangkan Ustaz Elvin Sasmita adalah founder dan motivator Parenting

\footnotetext{
$83 \mathrm{lbid}$.

84 "Samara series \# 1: "Kemanakah Kulabuhkan Hati ini"." Video YouTube, 1:45:53, dikirim oleh "YISC Al Azhar," Desember 20, 2020. https://youtu.be/eKuUiS50SeM.

85 "Merawat Rumah Tangga". Video Instagram, 00:00:54, dikirim oleh @ajobendri Juli 5, 2020, https://www.instagram.com/p/CCQjL4CAFml/?utm_ medium=copy_link

86 "Istri Menyimpan Perasaan Negatif kepada SuamiSolusi Keluarga I Ustaz Bendri Jaisyurrahman". Video YouTube, 5:04, dikirim oleh "Langkah Kita," Desember 11 , 2020.

https://www.youtube.com/watch?v=yk6SmRY9A88\&li st=PL0z35K6R87rcuHNQoAe0-xz6MdyneEGxs

87 Redaksi, "Background," accessed May 19, 2021 http://langkahkita.id/about-us/.

88 Redaksi, "Bendri Jaisyurrahman."
}

Nabawiyah.com, penulis buku Inspirasi dari Rumah Cahaya dan Kemanakah Kulabuhkan Hati ini, serta pengajar Madrasah dan Akademi Guru Al-Fatih. ${ }^{89} \mathrm{Hal}$ ini, sesuai dengan syarat dai dari landasan teori bahwa dai harus memiliki kemampuan pengetahuan di bidang pengetahuan seputar persiapan menikah dan membina keluarga. ${ }^{90} \mathrm{Di}$ samping itu, keduanya juga memiliki kemampuan di bidang Al-Qur'an dan hadis terkait tema persiapan menikah dalam pembacaannya dan pemaknaannya. ${ }^{91}$ Remaja cenderung lebih percaya kepada ustaz karena faktor kompetensi, kebajikan, dan integritas yang dimiliki didasarkan pada Al-Quran dan hadist. ${ }^{92}$ Dari asumsi tersebut, maka dai kajian Samara masih bisa memenuhi keinginan remaja.

Syarat dai berikutnya adalah memiliki kemampuan berkomunikasi agar pesan yang disampaikan mudah diterima mad'uw. $^{93}$ Remaja memiliki kepribadian lebih suka menuruti teman yang bersahabat dan yang memahami kebutuhannya. ${ }^{94}$ Dengan pembawaan yang ringan untuk remaja dan banyak bahan candaan akan membuat peserta seperti sedang bersama teman yang bersahabat, bukan bersama orang tua. ${ }^{95}$

89 "Samara series \# 1: "Kemanakah Kulabuhkan Hati ini"." Video YouTube, 1:45:53, dikirim oleh "YISC Al Azhar," Desember 20, 2020. https://youtu.be/eKuUiS50SeM.

${ }^{90}$ Amin, Ilmu Dakwah, 79-85.

91 "Samara series \# 1: "Kemanakah Kulabuhkan Hati ini"." Video YouTube, 1:45:53, dikirim oleh "YISC Al Azhar," Desember 20, 2020. https://youtu.be/eKuUiS50SeM.

92 Silvia Desmawarita and Linda Aryani, "Kepercayaan Mahasiswa Terhadap Ustadz: Pendekatan Indigenous Psikologi," Jurnal Psikologi UIN Sultan Syarif Kasim Riau 10, no. 2 (2014): 126, doi:10.24014/jp.v10i2.1190.

${ }^{93}$ Amin, Ilmu Dakwah, 79-85.

${ }^{94}$ Saputro, "Memahami Ciri Dan Tugas Perkembangan Masa Remaja," 26.

95 "Samara series \# 5: "Sudah Terlanjur Cinta Ternyata Bukan Untukku"." Video YouTube, 1:15:07, dikirim oleh 
Remaja juga memiliki keingintahuan besar terhadap hal-hal baru, ${ }^{96}$ maka dengan adanya kemampuan dai dalam memahami sumber Islam dan perihal pranikah maka bisa menjadi kelebihan tersendiri untuk memuaskan keingintahuan remaja.

Dengan kemampuan di bidang pengetahuan persiapan menikah, penguasaan sumber Islam, dan komunikasi yang dimiliki mendukung pencapaian tujuan dakwah yakni mengubah pola pikir dan perilaku remaja dalam menjalani masa sebelum menikah sesuai dengan ajaran Islam. Adanya kemampuan tersebut mendukung kesuksesan penyampaian materi terkait pranikah.

Ketiga, unsur mitra dakwah. Kajian ini untuk remaja dari anggota YISC Al-Azhar atau orang umum. Selain secara luring, kajian ini juga daring (diunggah di YouTube resmi YISC Al-Azhar). Anggota YISC Al-Azhar berdomisili di daerah Jabodetabek yang merupakan kawasan perkotaan. ${ }^{97}$ Anak perkotaan pasti tidak luput dari arus modernisasi yang menyuguhkan gaya hidup yang kadang tidak islami dengan berbagai media, entah dari website, media sosial, atau pergaulan mereka. Dari dasar teori juga menguatkan kalau mereka juga mudah dipengaruhi oleh teman sebayanya. ${ }^{98}$

"YISC Al Azhar," Desember 20, 2020. https://youtu.be/Dsat6wG0ba8.

${ }^{96}$ Saputro, "Memahami Ciri Dan Tugas Perkembangan Masa Remaja," 29.

97 Redaksi, "Statistik Keanggotaan," accessed May 22, 2021, http://www.yisc-alazhar.or.id/profil/.

${ }^{98}$ Saputro, "Memahami Ciri Dan Tugas Perkembangan Masa Remaja," 26.

99 Euis Sunarti et al., "Resiliensi Remaja: Perbedaan Berdasarkan Wilayah, Kemiskinan, Jenis Kelamin, Dan Jenis Sekolah," Jurnal Ilmu Keluarga Dan Konsumen 11, no. 2 (May 2018): 157-68, doi:10.24156/jikk.2018.11.2.157.
Kebutuhan akan eksistensi diri, perhatian dari lawan jenis dan lingkungannya ini jika tidak diarahkan dengan benar membuahkan perilaku yang bernilai kedosaan. Hal ini, selaras dengan studi terkait remaja di perkotaan oleh Euis Sunarti dkk. Yang menyimpulkan bahwa remaja di perkotaan lebih sering melakukan seks bebas, terlibat membolos, terlibat miras dibandingkan remaja di pedesaan. Remaja perempuan lebih sering diajak dan dipaksa melakukan seks bebas, sementara remaja laki-laki lebih sering terlibat merokok dan diajak tawuran. ${ }^{99}$

Karakter remaja sebagai mitra dakwah yang demikian memengaruhi proses dakwah yang diselenggarakan oleh Kajian Samara. Materi yang disampaikan tidak lepas dari contoh problem free sex, ${ }^{100}$ cara mengendalikan keinginan untuk mendapatkan perhatian dari lawan jenis, memilih pasangan yang seiman walau ada non muslim yang terlihat lebih menarik atau memberikan perhatian, ${ }^{101}$ dan lainnya. Dai juga mencoba memberikan bahan candaan, menggunakan bahasa gaul dengan lagu anak muda, ${ }^{102}$ agar suasana tidak kaku sehingga mad'uw merasa sedang bersama dengan teman sebayanya. ${ }^{103}$

\footnotetext{
100 Samara series \# 4: "Kamu, Kemungkinan Yang Aku Semogakan"." Video YouTube, 1:24:06, dikirim oleh "YISC Al Azhar," Desember 20, 2020. https://youtu.be/RtYifOuVN1s.

101 "Samara series \# 4: "Kamu, Kemungkinan Yang Aku Semogakan"." Video YouTube, 1:24:06, dikirim oleh "YISC Al Azhar," Desember 20, 2020. https://youtu.be/RtYifOuVN1s

102 "Samara series \# 4: "Kamu, Kemungkinan Yang Aku Semogakan"." Video YouTube, 1:24:06, dikirim oleh "YISC Al Azhar," Desember 20, 2020. https://youtu.be/RtYifOuVN1s.

103 "Samara series \# 5: "Sudah Terlanjur Cinta Ternyata Bukan Untukku"." Video YouTube, 1:15:07, dikirim oleh
} 
Keempat, materi dakwah di Kajian Samara. Materi yang diberikan terdiri dari 9 seri, yakni: (1) Samara series 1 "Kemanakah Kulabuhkan Hati ini?"; ${ }^{104}$ (2) Samara series 2 "Menikah bukan sekedar update status"; 105 (3) Samara series 3 "Alasan memilih si dia"; ${ }^{106}$ (4) Samara series 4 "Kamu kemungkinan yang Aku semogakan; ${ }^{107}$ (5) Samara series 5 "Sudah terlanjur cinta ternyata bukan untukku"; ${ }^{108}$ (6) Samara series 6 "Ya Rabb Kenapa yang Lain Sudah Tetapi Aku Belum"; ;09 (7) Samara series 7 "Fatherman, Ayah tak selalu hadir setiap saat tapi selalu ada di waktu yang tepat"; $; 10$ (8) Samara series 8 "Nikah koq mahal?"; 111 dan (9) Samara series 9 "1000 Hari Mencari Cinta (Kiat Menyiapkan 5 Tahun Pernikahan)". ${ }^{112}$ Jika dikelompokkan, maka ada beberapa tema.

Tema pertama, pemahaman tentang hakikat pernikahan. Tujuan pernikahan adalah pembentukan ketakwaan di dalam keluarga.

"YISC Al Azhar," Desember 20, 2020. https://youtu.be/Dsat6wG0ba8.

104 "Samara series \# 1: "Kemanakah Kulabuhkan Hati ini"”" Video YouTube, 1:45:53, dikirim oleh "YISC Al Azhar," Desember 20, 2020. https://youtu.be/eKuUiS50SeM.

105 "Samara series \#2: "Menikah bukan sekedar update status"" Video YouTube, 1:24:13, dikirim oleh "YISC AI Azhar," Desember 20, 2020. https://youtu.be/jEmVqzNfz1E

106 "Samara series \#3: "Alasan Memilih Si Dia"” Video YouTube, 1:42:12, dikirim oleh "YISC Al Azhar," Desember 20, 2020. https://youtu.be/ffUudtT_-QI

107 "Samara series \# 4: "Kamu, Kemungkinan Yang Aku Semogakan"." Video YouTube, 1:24:06, dikirim oleh "YISC Al Azhar," Desember 20, 2020. https://youtu.be/RtYifOuVN1s.

108 "Samara series \# 5: "Sudah Terlanjur Cinta Ternyata Bukan Untukku"." Video YouTube, 1:15:07, dikirim oleh "YISC Al Azhar," Desember 20, 2020. https://youtu.be/Dsat6wG0ba8.

109 "Samara series \# 6: "Ya Rabb Kenapa Yang Lain Sudah Tetapi Aku Belum?"." Video YouTube, 1:22:53, dikirim oleh "YISC Al Azhar," Desember 20, 2020. https://youtu.be/-DJrYW4NvPM.

110 "Samara series \#7: "Fatherman (Ayah Tak Selalu Hadir Setiap Saat Tapi Selalu Ada di Waktu Yang
Nikah didasari niat untuk ibadah dan diisi dengan ibadah. ${ }^{113}$ Tema ini dibahas di seri pertama dan kedua. Tema kedua, cara memilih pasangan. Kriteria utama memilih pasangan adalah seiman, orang yang bertakwa, bukan orang non muslim atau lemah keimanannya. ${ }^{114}$ Biasanya memilih pasangan diistilahkan dengan melihat sekufu/setara dalam hal iman, penampilan, harta, keturunan. Kualitas keimanan menjadi hal yang utama yang dipertimbangkan dalam memilih pasangan. Hal-hal lain, selain iman selanjutnya bisa dipertimbangkan karena merupakan fitrah, kebutuhan masing-masing orang. ${ }^{115}$ Tema ini dibahas di seri ke-3 dan ke-4.

Tema ketiga, cara dalam menyelesaikan masalah saat pemilihan pasangan yakni saat cinta bertepuk sebelah tangan, ${ }^{116}$ saat ada kendala tidak segera menemukan calon

Tepat"” Video YouTube, 1:39:24, dikirim oleh "YISC Al Azhar," Desember 20, 2020. https://youtu.be/dXdpjYPJRSE

111 "Samara series \# 8: "Nikah Koq Mahal?"." Video YouTube, 1:15:07, dikirim oleh "YISC Al Azhar," Desember 20, 2020. https://youtu.be/XvHCcJnyTw4.

112 "Samara series \# 9: "1000 Hari Mencari Cinta (Kiat Menyiapkan 5 Tahun Pernikahan)"." Video YouTube. 38:52, dikirim oleh "YISC Al Azhar," Desember 20, 2020. https://youtu.be/SYWBC2KoDBU.

113 "Samara series \# 1: "Kemanakah Kulabuhkan Hati ini"." Video YouTube, 1:45:53, dikirim oleh "YISC Al Azhar," Desember 20, 2020. https://youtu.be/eKuUiS50SeM.

114 "Samara series \# 4: "Kamu, Kemungkinan Yang Aku Semogakan"." Video YouTube, 1:24:06, dikirim oleh "YISC Al Azhar," Desember 20, 2020. https://youtu.be/RtYifOuVN1s.

115 "Samara series \# 1: "Kemanakah Kulabuhkan Hati ini"." Video YouTube, 1:45:53, dikirim oleh "YISC Al Azhar," Desember 20, 2020. https://youtu.be/eKuUiS50SeM.

116 "Samara series \# 5: "Sudah Terlanjur Cinta Ternyata Bukan Untukku"." Video YouTube, 1:15:07, dikirim oleh "YISC Al Azhar," Desember 20, 2020. https://youtu.be/Dsat6wG0ba8. 
pasangan, $^{117}$ saat ada kendala biaya pernikahan yang mahal. ${ }^{118}$ Tema ini dibahas di seri ke-5, 6, dan 8. Tema keempat terkait hal-hal yang dipersiapkan untuk menikah pada 5 tahun pertama yakni terkait dengan adanya perasaan cinta yang progresif, sehingga ibadah bisa didasari cinta. Adanya sikap konsisten mencintai walaupun pasangan memiliki kelemahan. ${ }^{119}$ Peran lakilaki sebagai kepala keluarga karena daya rasionalnya lebih unggul dibanding perempuan. ${ }^{120}$ Tema ini dibahas di seri ke-7 dan ke-9.

Materi yang disampaikan sesuai dengan kebutuhan remaja yang ingin memiliki pasangan. Jika rasa ketertarikan ini tidak dibekali nilai Islam, tentulah akan menggunakan prinsip nilai kebebasan/lainnya. Menurut dai, efek adanya kebebasan remaja ketika tertarik dengan lawan jenis dan tanpa dasar agama adalah banyaknya kasus free sex, ${ }^{121}$ terlalu mendambakan/memikirkan pasangan hingga lupa dengan agama, ${ }^{122}$ menikah dengan orang non Islam, dan keluar dari Islam mengikuti agama pasangannya. ${ }^{123}$

117 "Samara series \# 6: "Ya Rabb Kenapa Yang Lain Sudah Tetapi Aku Belum?"." Video YouTube, 1:22:53, dikirim oleh "YISC Al Azhar," Desember 20, 2020. https://youtu.be/-DJrYW4NvPM.

118 "Samara series \# 8: "Nikah Koq Mahal?"." Video YouTube, 1:15:07, dikirim oleh "YISC Al Azhar," Desember 20, 2020. https://youtu.be/XvHCcJnyTw4.

119 "Samara series \# 9: "1000 Hari Mencari Cinta (Kiat Menyiapkan 5 Tahun Pernikahan)"." Video YouTube. 38:52, dikirim oleh "YISC Al Azhar," Desember 20, 2020. https://youtu.be/SYWBC2KoDBU.

120 "Samara series \# 1: "Kemanakah Kulabuhkan Hati ini"” Video YouTube, 1:45:53, dikirim oleh "YISC AI Azhar," Desember 20, 2020. https://youtu.be/eKuUiS50SeM.

${ }^{121}$ Samara series \# 4: "Kamu, Kemungkinan Yang Aku Semogakan"." Video YouTube, 1:24:06, dikirim oleh "YISC Al Azhar," Desember 20, 2020. https://youtu.be/RtYifOuVN1s.

122 "Samara series \# 5: "Sudah Terlanjur Cinta Ternyata Bukan Untukku"." Video YouTube, 1:15:07, dikirim oleh
Materi terkait hakikat pernikahan sebagai pijakan orientasi dari pernikahan. Dai menyampaikan bahwa ada muslim yang menikah bukan untuk orientasi takwa, tapi untuk menyalurkan kebutuhan biologisnya, mencari pengakuan dari lingkungan, atau hanya memenuhi kebutuhan perhatiannya saja. ${ }^{124}$ Dengan dasar orientasi pernikahan bisa menjadi patokan untuk mengarahkan alasan/motif remaja yang ingin menikah agar sesuai dengan ajaran Islam. Dalam faktanya, remaja yang melakukan free sex salah satunya karena kebutuhan afiliasi. ${ }^{125}$ Hal ini, membuktikan bahwa materi disesuaikan dengan kondisi psikologis remaja.

Materi kajian ini juga sesuai dengan masalah yang dialami remaja saat mencari/membina hubungan dengan calon pasangan. Dai menyampaikan bahwa ada remaja yang kebingungan memilih pasangan yakni sudah terlanjur cinta tapi imannya lemah dan non muslim. ${ }^{126}$ Selain itu, ada kasus patah hati dan ada yang sudah terlalu mencintai seseorang tapi ternyata orang itu memilih yang lain. ${ }^{127}$ Dalam faktanya, memang ada

"YISC Al Azhar," Desember 20, 2020. https://youtu.be/Dsat6wG0ba8.

123 "Samara series \# 4: "Kamu, Kemungkinan Yang Aku Semogakan"." Video YouTube, 1:24:06, dikirim oleh "YISC Al Azhar," Desember 20, 2020. https://youtu.be/RtYifOuVN1s.

124 "Samara series \# 1: "Kemanakah Kulabuhkan Hat ini"." Video YouTube, 1:45:53, dikirim oleh "YISC Al Azhar," Desember 20, 2020. https://youtu.be/eKuUiS50SeM.

125 Satyana, "Kebutuhan Afiliasi Dan Perilaku Seksual Pranikah Pada Mahasiswa," 162.

126 "Samara series \# 4: "Kamu, Kemungkinan Yang Aku Semogakan"." Video YouTube, 1:24:06, dikirim oleh "YISC Al Azhar," Desember 20, 2020. https://youtu.be/RtYifOuVN1s.

127 "Samara series \# 5: "Sudah Terlanjur Cinta Ternyata Bukan Untukku"." Video YouTube, 1:15:07, dikirim oleh "YISC Al Azhar," Desember 20, 2020. https://youtu.be/Dsat6wG0ba8. 
remaja yang mengalami depresi ketika cintanya tidak mulus, misalnya patah hati. ${ }^{128}$ Ada pula yang memiliki anggapan bahwa kriteria pemilihan pasangan bukan di aspek keimanan. ${ }^{129}$ Jika tidak dipecahkan secara islami, tentu berdampak negatif. Seperti yang disampaikan Santrock, remaja akan lari ke narkoba, free sex, dan kenakalan lain. ${ }^{130}$ Materi ini disampaikan, sebagai wujud upaya preventif dan kuratif saat remaja mengalami depresi/kesedihan. Jika nantinya remaja mengalami depresi, tidak akan melakukan tindakan melanggar norma Islam.

Materi terkait problem keluarga dan pemecahannya, memberikan gambaran pada remaja terkait hal-hal yang dipersiapkan agar tidak mengalami kegagalan saat berkeluarga. Materi ini bersifat preventif. Remaja akan berpotensi akan berupaya memperbaiki dirinya agar tidak mengalami masalah serupa. Samara series 7 menunjukkan bahwa tugas ayah selain menafkahi, namun juga menjaga hubungan erat dengan anggota keluarga. ${ }^{131}$ Remaja laki-laki akan berpotensi semangat belajar mengelola waktu, emosi, berempati agar sukses menjadi ayah.

Materi yang diberikan mudah dipahami dan mudah untuk diamalkan. Paparan penjelasannya diberikan contoh nyata yang

128 M, Sri, AA, "Hubungan Kegagalan Cinta Dengan Terjadinya Kejadian Depresi Pada Remaja (Suatu Studi Kelas Sebelas Di SMAN 3 Bojonegoro)," 23.

129 Amalia and Ali Akbar, "Konseling Islam Perannya Bagi Pemilihan Pasangan Dan Kesiapan Pernikahan," 129.

130 M, Sri, AA, "Hubungan Kegagalan Cinta Dengan Terjadinya Kejadian Depresi Pada Remaja (Suatu Studi Kelas Sebelas Di SMAN 3 Bojonegoro)," 23.

131 "Samara series \#7: "Fatherman (Ayah Tak Selalu Hadir Setiap Saat Tapi Selalu Ada di Waktu Yang Tepat"" Video YouTube, 1:39:24, dikirim oleh "YISC Al Azhar," Desember 20, 2020. https://youtu.be/dXdpjYPJRSE praktis. Misalkan saja, kiat agar tidak terlalu cinta pada seseorang yang belum tentu jodohnya adalah dengan menghindari komunikasi yang intensif, memperbanyak ibadah, jangan mengumbar perasaan ke orang tersebut, berlindung pada Allah jika terlanjur jatuh cinta dengan doa, membuat jadwal kegiatan agar sibuk, dan tidak menyendiri. ${ }^{132}$ Bagi remaja yang masih kurang pengetahuan butuh dibimbing dengan bahasa yang mudah dipahami. Pada comment Instagram, puluhan peserta menyatakan bahwa pembahasannya menarik dan me-mention temantemannya. ${ }^{133} \mathrm{Hal}$ ini, membuktikan bahwa penjelasan materinya diterima oleh mad'uw.

Materi Kajian Samara memuat pesan utama dan penunjang seperti yang disampaikan oleh Ali Aziz. ${ }^{134}$ Pesan utama yakni bersumber dari Al-Qur'an dan hadis. Contohnya, saat menjelaskan orientasi pernikahan adalah membentuk anggota keluarga yang takwa dengan memberikan dasar Al-Qur'an surat An Nisa: $1 .{ }^{135}$ Selain itu, pesan penunjang saat ada kisah sahabat dan pengalaman teladan. Khadijah membatasi interaksi dengan orang yang dicintai yakni Nabi saw. dengan mengirim orang untuk mengamati Nabi, kisah Fatimah yang tidak agresif bertemu dan mengobrol dengan Ali walaupun begitu mengagumi. ${ }^{136}$

132 "Samara series \# 5: "Sudah Terlanjur Cinta Ternyata Bukan Untukku"." Video YouTube, 1:15:07, dikirim oleh "YISC Al Azhar," Desember 20, 2020. https://youtu.be/Dsat6wG0ba8.

133 Instagram YISC Al-Azhar @yisc.alazhar

134 Aziz, Ilmu Dakwah, 318-330.

135 "Samara series \# 1: "Kemanakah Kulabuhkan Hati ini"." Video YouTube, 1:45:53, dikirim oleh "YISC Al Azhar," Desember 20, 2020. https://youtu.be/eKuUiS50SeM.

136 Samara series \# 5: "Sudah Terlanjur Cinta Ternyata Bukan Untukku"." Video YouTube, 1:15:07, dikirim oleh "YISC Al Azhar," Desember 20, 2020. https://youtu.be/Dsat6wG0ba8. 
Ustaz Bendri J. sering memberikan contoh kasus yang terjadi di lapangan saat orang melakukan persiapan menikah atau menikah. Contohnya saja, saat menjelaskan kisah remaja yang terlanjur cinta dengan orang yang lemah imannya, ${ }^{137}$ kisah pertengkaran rumah tangga karena perselingkuhan suaminya, ${ }^{138}$ kisah pasangan yang terlanjur free sex saat $\mathrm{H}-3$ hari pernikahan yang berujung kematian laki-laki dan kehamilan perempuan sehingga menimbulkan aib, ${ }^{139}$ kisah istri yang menerima kelemahan suaminya, dan lainnya. Kisah itu diambil di era kekinian sehingga kontekstual, mudah dicerna, dekat dengan remaja. Jika melihat asumsi remaja yang lebih percaya dengan dai karena faktor kompetensi didasarkan pada Al-Quran dan hadis, ${ }^{140}$ tentu adanya landasan yang kuat akan memperkuat kepercayaan dan semangat remaja untuk menjalankan materi kajian. Hal ini, juga akan menguatkan remaja yang beragama karena ikut-ikutan. ${ }^{141}$

Kelima, unsur metode dakwah di Kajian Samara. Dalam penyampaian kajian selama 1,5-2 jam. Metode yang banyak digunakan adalah bil hikmah karena dai memberikan pemaparan data dari berbagai pendekatan, entah Al-Qur'an, hadis, kisah sahabat, kisah

137 "Samara series \# 1: "Kemanakah Kulabuhkan Hati ini"." Video YouTube, 1:45:53, dikirim oleh "YISC Al Azhar," Desember 20, 2020. https://youtu.be/eKuUiS50SeM.

138 "Samara series \# 4: "Kamu, Kemungkinan Yang Aku Semogakan"." Video YouTube, 1:24:06, dikirim oleh "YISC Al Azhar," Desember 20, 2020. https://youtu.be/RtYifOuVN1s.

139 Samara series \# 4: "Kamu, Kemungkinan Yang Aku Semogakan"." Video YouTube, 1:24:06, dikirim oleh "YISC Al Azhar," Desember 20, 2020. https://youtu.be/RtYifOuVN1s.

140 Desmawarita and Aryani, "Kepercayaan Mahasiswa Terhadap Ustadz: Pendekatan Indigenous Psikologi," 126.

141 Hamali, "Syaiful Hamali, Karakteristik Keberagamaan," 10-11. dan pengalaman teladan, dan berita untuk menguatkan argumennya. Misalkan saja, menunjukkan bahwa orientasi pernikahan adalah membentuk anggota keluarga yang takwa dengan memberikan dasar Al-Qur'an surat An Nisa: 1. Adapun kisah Julaibib (sahabat Nabi saw.) walaupun tidak berkedudukan, nasabnya tidak jelas, tidak kaya namun beriman maka dijodohkan oleh Rasul dengan anak gadis pembesar di wilayah itu. ${ }^{142}$ Dalam memilih pasangan yang utama adalah keimanannya, hal berikutnya adalah masalah penampilan, harta, keturunan. Orang yang beriman akan lebih tinggi derajatnya dengan orang yang tidak beriman walaupun hartanya melimpah, penampilannya menawan, dan lainnya. ${ }^{143}$ Ada lagi kisah Talhah bin Ubaidillah yang menyesal setelah diingatkan Allah untuk tidak mengharapkan jandanya Aisyah, istri Nabi saw. ${ }^{144}$ Nasihat itu untuk menjawab pandangan remaja yang mengutamakan usia, suku, status pernikahan, pendapatan dan pekerjaan dalam memilih pasangan. ${ }^{145}$

Dai menggunakan metode mau'idzatil hasanah juga. Hal ini, karena dai sering menggunakan kisah sahabat Nabi, kisah pasangan-pasangan yang melalui proses pranikah dan nikah, dan memberikan

142 Samara series \# 4: "Kamu, Kemungkinan Yang Aku Semogakan"." Video YouTube, 1:24:06, dikirim oleh "YISC Al Azhar," Desember 20, 2020. https://youtu.be/RtYifOuVN1s.

143 Samara series \# 4: "Kamu, Kemungkinan Yang Aku Semogakan"." Video YouTube, 1:24:06, dikirim oleh "YISC Al Azhar," Desember 20, 2020. https://youtu.be/RtYifOuVN1s.

144 Samara series \# 4: "Kamu, Kemungkinan Yang Aku Semogakan"." Video YouTube, 1:24:06, dikirim oleh "YISC Al Azhar," Desember 20, 2020. https://youtu.be/RtYifOuVN1s.

145 Amalia and Ali Akbar, "Konseling Islam Perannya Bagi Pemilihan Pasangan Dan Kesiapan Pernikahan," 129. 
nasihat kepada mad'uw. Kisah sahabat yang diangkat misal kisah Julaibib. ${ }^{146}$ Ada kisah orang yang free sex beberapa hari sebelum menikah dan akhirnya calon suami meninggal karena kecelakaan, pihak perempuan menanggung malu karena hamil di luar nikah. ${ }^{147}$ Remaja yang dalam berpacaran sudah melakukan free sex, ${ }^{148}$ bisa mengambil pelajaran. Mereka bisa mengendalikan kebutuhan afiliasinya. ${ }^{149}$ Nasihat seperti ini memberikan pelajaran kepada remaja tanpa menyakiti hati/perasaannya dan menghargai kedirian remaja. Memang remaja secara psikologis, sulit diberikan nasihat oleh orang tua karena terlalu percaya diri dan emosional. ${ }^{150}$

Pemakaian metode bil hikmah dan mau'idzatil hasanah kepada remaja sesuai dengan pendapat ahli dan hasil studi terkait. Syekh M. Abduh dalam Nurbini menyatakan bahwa metode bil hikmah cocok untuk orang cerdik pandai, yang berpikir kritis dan akademis. Metode mau'idzatil hasanah cukup untuk yang awam dan kebanyakan tanpa latar belakang pendidikan tinggi. Sedangkan mujadalah untuk yang bukan cerdik cendekiawan, bukan pula kalangan awam. ${ }^{151}$ Dari sejumlah peserta kajian ada sebagian kecil yang sudah mulai mendalami hal-hal terkait persiapan menikah, sehingga harus menunjukkan bil hikmah. Peserta mampu menjawab makna Q.S. An-Nisa: $1^{152}$

\footnotetext{
146 Samara series \# 4: “Kamu, Kemungkinan Yang Aku Semogakan"." Video YouTube, 1:24:06, dikirim oleh "YISC Al Azhar," Desember 20, 2020. https://youtu.be/RtYifOuVN1s.

147 Samara series \# 4: "Kamu, Kemungkinan Yang Aku Semogakan"." Video YouTube, 1:24:06, dikirim oleh "YISC Al Azhar," Desember 20, 2020. https://youtu.be/RtYifOuVN1s.

${ }^{148}$ Rahyani et al., "Perilaku Seks Pranikah Remaja," 181. 149 Rosidah, "Religiusitas, Harga Diri, Dan Perilaku Seksual Pranikah Remaja," 592.

150 Saputro, "Memahami Ciri Dan Tugas Perkembangan Masa Remaja," 26.
}

dan menjawab standar pasangan yang baik dalam Islam. ${ }^{153}$ Namun, banyak pula yang awam, ketika diberikan pertanyaan menjawab keliru/diam, sehingga bisa menggunakan metode mau'idzatil hasanah. Remaja juga punya pandangan yang keliru tentang kriteria pemilihan pasangan, perilaku saat pacaran. ${ }^{154}$ Dengan demikian, penggunaan metode kajian masih sesuai dengan psikologi remaja.

\section{Metode bil hikmah dan mau'idzatil hasanah} masih menunjang penyampaian materi terkait persiapan menikah. Penjelasan yang jelas disertai argumentasi yang logis dan dalil sumber ajaran Islam semakin menguatkan kualitas materi yang disampaikan. Adanya nasihat dengan memberikan contoh dari tokoh sejarah lebih mengkonkritkan materi persiapan menikah.

Kedua metode yang digunakan masih menunjang tercapainya tujuan kajian yakni untuk membina generasi muda agar dapat menyiapkan pernikahan yang berorientasi takwa. Penggunaan metode bil hikmah memberikan kekuatan data dan argumentasi untuk membuat peserta sepakat pada materinya. Di samping itu, metode mau'idzatil hasanah memberikan sentuhan rasa dan semangat untuk menerapkan materi sehingga peserta tergugah untuk sadar dan mau menjalankan hal yang benar.

\footnotetext{
151 Nurbini, "Bahasa Dakwah Untuk Kalangan Remaja Terpelajar," 119.

152 "Samara series \# 1: "Kemanakah Kulabuhkan Hati ini"”' Video YouTube, 1:45:53, dikirim oleh "YISC Al Azhar," Desember 20, 2020.

153 Samara series \# 4: "Kamu, Kemungkinan Yang Aku Semogakan"." Video YouTube, 1:24:06, dikirim oleh "YISC Al Azhar," Desember 20, 2020. https://youtu.be/RtYifOuVN1s.

154 Amalia and Ali Akbar, "Konseling Islam Perannya Bagi Pemilihan Pasangan Dan Kesiapan Pernikahan," 129.
} 
Keenam, unsur media dakwah di Kajian Samara. Media dakwah yang digunakan yakni audio visual (YouTube) dan tatap muka langsung. Kalangan remaja pada era kekinian sudah tidak asing dengan dunia internet dan media sosial. Jika menggunakan media YouTube tentu sangat cocok bagi mereka. Berdasarkan hasil studi Aprilia, Sriati, dan Hendrawati, sebagian besar remaja (51,4\%) mengalami kecanduan media sosial tingkat rendah, sisanya mengalami kecanduan media sosial tingkat tinggi. ${ }^{155}$ Berdasarkan sebuah studi yang dilakukan oleh Variety Magazine pada tahun 2014, enam dari sepuluh remaja dengan usia 13-18 tahun terpengaruh dengan menonton video di YouTube. ${ }^{156}$ Jika remaja memakai media sosial maka mereka dianggap mengikuti gaya teman-teman mereka. Karakter remaja memang lebih suka menuruti gaya perilaku teman sebaya dibandingkan orang tua atau orang lainnya. ${ }^{157} \mathrm{Hal}$ ini, membuktikan bahwa media yang dipilih disesuaikan dengan kebutuhan dan karakter remaja dalam mengakses informasi, khususnya kajian.

\section{Kesimpulan}

Kajian Samara YISC Al-Azhar memiliki tujuan membina generasi muda agar menjadi generasi yang mempertahankan dan memperjuangkan nilai-nilai Islam saat proses persiapan menikah. Persiapan menikah yakni mencari calon pasangan, membina hubungan, dan mengantisipasi

${ }^{155}$ Sri Hendrawati, Rizki Aprilia, and Aat Sriati, "Tingkat Kecanduan Media Sosial Pada Remaja," Jnc 3, no. 1 (2020): 41, doi:10.24198/jnc.v3i1.26928.

${ }^{156}$ Asrul. Fachruddin, Sutiyana. Jaya, “Perilaku Remaja Dalam Penggunaan Media Sosial YouTube Sebagai Media Baru 4.0," in KOMUNIKASI, PEMBANGUNAN, DAN MEDIA (Kendari: Komunika, 2020), 18, masalah saat berkeluarga. Kajian Samara sebagai usaha dakwah pranikah islami untuk remaja yang berkualitas baik. Hal tersebut, karena semua unsur dakwah meliputi tujuan, materi, dai, metode, dan media dakwah di kajian Samara sudah menyesuaikan aspek psikologis remaja sebagai mad'uw. Remaja yang termasuk mad'uw kajian adalah remaja muslim umum, terutama di wilayah Jabodetabek. Dalam persiapan menikah, aspek psikologis remaja yang diperhatikan meliputi: (1) persepsi terkait pernikahan (tujuan, usia menikah, kriteria calon pasangan, dan proses membina hubungan); (2) kebutuhan dalam membina hubungan; dan (3) problem saat membina hubungan (patah hati, seks pranikah, depresi, dan lainnya). Hal tersebut, menjadi keunggulan dari kajian Samara. Selain itu, kajian ini sebagai salah satu upaya agar remaja terhindar dari perilaku kedosaan/kenakalan saat remaja dan mengalami kegagalan dari pernikahannya di kemudian hari.

Implikasi dari studi ini, secara teoretis adalah menambah temuan baru terkait adanya usaha dakwah terkait persiapan pernikahan kepada remaja. Upaya menyukseskan persiapan pranikah tidak hanya bisa dilihat dari kaca mata pendidikan untuk calon pengantin saja, namun bisa dengan jalan dakwah pada remaja. Penyadaran ini dilakukan secara berkesinambungan, dimulai saat sudah menginjak masa remaja, sehingga terjadi proses penanaman nilai yang baik. Sedangkan implikasi studi ini, secara praktis yakni bisa menjadi inspirasi

https://uho.ac.id/prodi/pemerintahan/wpcontent/uploads/sites/53/2020/02/PERILAKUREMAJA-DALAM-PENGGUNAAN-MEDIA-SOSIALYOUTUBE-SEBAGAI-MEDIA-dikonversi.pdf.

157 Saputro, "Memahami Ciri Dan Tugas Perkembangan Masa Remaja," 26. 
baru bagi organisasi atau pegiat dakwah remaja ketika menghadapi masalah pranikah remaja perlu mempertimbangkan aspek psikologis remaja agar dakwah diterima dan bermanfaat bagi remaja entah dalam upaya preventif dan kuratif dalam pemecahan masalah-masalah remaja terkait persiapan menikah. Walhasil, remaja akan terhindar dari perilaku kedosaan dan mulai mempersiapkan diri melakukan hal positif agar pernikahannya kelak tidak gagal.

\section{Bibliografi}

Alam, Samsul. "Pembinaan Pranikah Dalam Peningkatan Pemahaman Keagamaan Calon Pengantin Di KUA Kecamatan Sleman." G-Couns: Jurnal Bimbingan Dan Konseling 4, no. 1 (2020): 25. doi:10.31316/g.couns.v4i1.447.

Aliyudin. "Prinsip-Prinsip Metode Dakwah Menurut Al-Quran." IImu Dakwah: Academic Journal for Homiletic Studies 4, no. 15 (2010): 1007-22. doi:10.15575/idajhs.v5i16.360. Amalia, Rizqi Maulida, and Muhammad Yudi Ali Akbar. "Konseling Islam Perannya Bagi Pemilihan Pasangan Dan Kesiapan Pernikahan." JURKAM: Jurnal Konseling Andi Matappa 1, no. 2 (2017): 125. doi:10.31100/jurkam.v1i2.58.

Amin, Samsul Munir. Ilmu Dakwah. Jakarta: Amzah, 2009.

Aziz, Ali. Ilmu Dakwah. Jakarta: Prenadamedia, 2016.

Bariyyah Hidayati, Khoirul, and . M Farid. "Konsep Diri, Adversity Quotient Dan Penyesuaian Diri Pada Remaja." Persona:Jurnal Psikologi Indonesia 5, no. 02 (2016): 137-44. doi:10.30996/persona.v5i02.730.

Cholis Akbar. "Sejak 2004-2011 Ada 1190 Pernikahan Beda Agama." Accessed August 27, 2021. https://www.hidayatullah.com/berita/nasional/read/2012/03/31/58025/sejak-20042011-ada-1190-pernikahan-beda-agama.html.

Desmawarita, Silvia, and Linda Aryani. "Kepercayaan Mahasiswa Terhadap Ustadz: Pendekatan Indigenous Psikologi." Jurnal Psikologi UIN Sultan Syarif Kasim Riau 10, no. 2 (2014): 11927. doi:10.24014/jp.v10i2.1190.

Fachruddin, Sutiyana. Jaya, Asrul. "Perilaku Remaja Dalam Penggunaan Media Sosial YouTube Sebagai Media Baru 4.0." In KOMUNIKASI, PEMBANGUNAN, DAN MEDIA, 18. Kendari: Komunika, 2020. https://uho.ac.id/prodi/pemerintahan/wpcontent/uploads/sites/53/2020/02/PERILAKU-REMAJA-DALAM-PENGGUNAAN-MEDIASOSIAL-YOUTUBE-SEBAGAI-MEDIA-dikonversi.pdf.

Fajarini, Febri, and Nuristighfari Masri Khaerani. "Kelekatan Aman, Religiusitas, Dan Kematangan Emosi Pada Remaja." Jurnal Psikologi Integratif 2, no. 1 (2014): 22-29. doi:https://doi.org/10.14421/jpsi.2014.\%25x.

Haidar, Galih, and Nurliana Cipta Apsari. "Pornografi Pada Kalangan Remaja." Prosiding Penelitian Dan Pengabdian Kepada Masyarakat 7, no. 1 (2020): 136. doi:10.24198/jppm.v7i1.27452.

Hakim, Muhammad Lutfi. "Kursus Pra-Nikah: Konsep Dan Implementasinya (Studi Komparatif Antara BP4 KUA KEC. Pontianak Timur Dengan GKKB Jemaat Pontianak)." Al-Maslahah Jurnal Ilmu Syariah 13, no. 2 (2017): 191. doi:10.24260/almaslahah.v13i2.924. 
Hamali, Syaiful. "Syaiful Hamali, Karakteristik Keberagamaan." Karakteristik Keberagaman Remaja Dalam Perspektif Psikologi 11, no. 1 (2016): 1-18. doi:https://doi.org/10.24042/ajsla.v11i1.1438.

Hendrawati, Sri, Rizki Aprilia, and Aat Sriati. "Tingkat Kecanduan Media Sosial Pada Remaja." Jnc 3, no. 1 (2020): 41-53. doi:10.24198/jnc.v3i1.26928.

Insan Khoirul Qolbi. "Kemenag - BP4 Perkuat Sinergi, Tekan Angka Perceraian." Accessed July 24, 2021. https://kemenag.go.id/read/kemenag-bp4-perkuat-sinergi-tekan-angkaperceraian-xkv8g.

Ishaq, Ropingi el. Pengantar IImu Dakwah: Studi Komprehensif Dakwah Dan Teori Ke Praktik. Malang: Madani, 2016.

Johar, Rama Dhini Permasari, and Hamda Sulfinadia. "Manajemen Konflik Sebagai Upaya Mempertahankan Keutuhan Rumah Tangga." Journal Al-Ahkam XXI, no. 1 (2020): 44-45. https://ejournal.uinib.ac.id/jurnal/index.php/alahkam/article/view/1476/pdf.

M, Sri, AA, Agus. "Hubungan Kegagalan Cinta Dengan Terjadinya Kejadian Depresi Pada Remaja (Suatu Studi Kelas Sebelas Di SMAN 3 Bojonegoro)." Jurnal Asuhan Kesehatan 7, no. 2 (2016): 23. http://ejournal.rajekwesi.ac.id/index.php/jurnal-penelitiankesehatan/article/view/133/115.

Nurbini. "Bahasa Dakwah Untuk Kalangan Remaja Terpelajar." Jurnal Dakwah XI, no. 1 (2011): 117. http://ejournal.uin-suka.ac.id/dakwah/jurnaldakwah/article/download/399/378.

Nurfauziyah, Alifah. "Bimbingan Pranikah Bagi Calon Pengantin Dalam Mewujudkan Keluarga Sakinah." Jurnal Bimbingan, Penyuluhan, Konseling, Dan Psikoterapi Islam 5, no. 4 (2017): 449. doi:https://doi.org/10.15575/irsyad.v5i4.

Ohee, Christine. Purnomo, Windhu. "Pengaruh Status Hubungan Berpacaran Terhadap Perilaku Pacaran Berisiko Pada Mahasiswa Perantau Asal Papua Di Kota Surabaya." The Indonesian Journal of Public Health 13, no. 2 (2019): 269. doi:10.20473/ijph.v13i2.2018.269-287.

Rahmatullah, Rahmatullah. "Analisis Penerapan Metode Dakwah Berdasarkan Karakteristik Mad'u Dalam Aktivitas Dakwah." Jurnal Mimbar: Media Intelektual Muslim Dan Bimbingan Rohani 2, no. 1 (2016): 55-71. doi:10.47435/mimbar.v2i1.286.

Rahyani, Komang Yuni, Adi Utarini, Siswanto Agus Wilopo, and Mohammad Hakimi. "Perilaku Seks Pranikah Remaja." Kesmas: National Public Health Journal 7, no. 4 (2012): 180. doi:10.21109/kesmas.v7i4.53.

Rangkuti, Anna Armeini, and Devi Oktaviani Fajrin. "Preferensi Pemilihan Calon Pasangan Hidup Ditinjau Dari Keterlibatan Ayah Pada Anak Perempuan." JPPP - Jurnal Penelitian Dan Pengukuran Psikologi 4, no. 2 (2015): 59-64. doi:10.21009/JPPP.042.03.

Redaksi. "Background." Accessed May 19, 2021. http://langkahkita.id/about-us/.

- - . "Bendri Jaisyurrahman." Accessed January 15, 2021. http://bendri.id.

- - . "Latar Belakang." Accessed April 15, 2021. http://www.yisc-alazhar.or.id/profil/.

-- . "Masjid Al-Azhar." Accessed December 4, 2020. www.alazhar.or.id/index.php/komunitas/.

---. "Qur'an Kemenag." Accessed March 22, 2021. https://quran.kemenag.go.id/sura/4.

- - . "Statistik Keanggotaan." Accessed May 22, 2021. http://www.yisc-alazhar.or.id/profil/.

-- -. "YISC Al-Azhar." Accessed December 4, 2020. www.yisc-alazhar.or.id/profil/. 
- - . "YISC Youth Islamic Study Club." Accessed December 4, 2020. http://www.alazhar.or.id/komunitas/yisc/.

Renel, Baiti. “Materi Dakwah Dan Kebutuhan Mad'uw (Studi Kasus Pada Majelis Taklim Nurul Qulub Di Kecamatan Baguala Kota Ambon)." Universitas Islam Negeri (UIN) Alauddin Makasar, 2012.

Rihardini, Tetty, and Yolanda S. "Persepsi Remaja Tentang Perilaku Seks Pranikah Di SMA X." EMBRIO 1, no. 1 (2012): 6-11. doi:10.36456/embrio.vol1.no0.a1190.

Rosidah, Anis. "Religiusitas, Harga Diri, Dan Perilaku Seksual Pranikah Remaja." Jurnal Psikologi 7, no. 2 (2012): 585-93. https://jurnal.unmer.ac.id/index.php/jpt/article/view/197/68.

Saputro, Khamim Zarkasih. "Memahami Ciri Dan Tugas Perkembangan Masa Remaja." Aplikasia: Jurnal Aplikasi Ilmu-Ilmu Agama 17, no. 1 (2018): 25. doi:10.14421/aplikasia.v17i1.1362.

Satyana, Alifia. "Kebutuhan Afiliasi Dan Perilaku Seksual Pranikah Pada Mahasiswa." Cognicia 8, no. 1 (2020): 162. doi:https://doi.org/10.22219/COGNICIA.Vol8.No1.157-168.

Sunarti, Euis, Intan Islamia, Nur Rochimah, and Milatul Ulfa. "Resiliensi Remaja: Perbedaan Berdasarkan Wilayah, Kemiskinan, Jenis Kelamin, Dan Jenis Sekolah." Jurnal IImu Keluarga Dan Konsumen 11, no. 2 (May 2018): 157-68. doi:10.24156/jikk.2018.11.2.157. Susanto, Tatut. Kimura, Rumiko. Tsuda, Akiko. et al. "Persepsi Remaja Dalam Perencanaan Keluarga Di Daerah Rural Dan Urban Kabupaten Jember, Provinsi Jawa Timur, Indonesia." Jurnal Keluarga Berencana 1, no. 1 (2016): 1-58. http://repository.unej.ac.id/handle/123456789/83656.

Sutopo, Ariseto Hadi and Arief, Adrianus. Terampil Mengolah Data Kualitatif Dengan NVINO. Jakarta: Kencana, 2010.

Tsania, Nurlita, Euis Sunarti, and D.K. Pranaji. "Karakteristik Keluarga, Kesiapan Menikah Istri, Dan Perkembangan Anak Usia 3-5 Tahun." Jurnal IImu Keluarga Dan Konsumen 8, no. 1 (2015): 28-37. doi:10.24156/jikk.2015.8.1.28. 
Sri Wahyuni 